\title{
Collaborative learning to unlock investments for functional ecological infrastructure: Bridging barriers in social-ecological systems in South Africa $^{\text {मे }}$
}

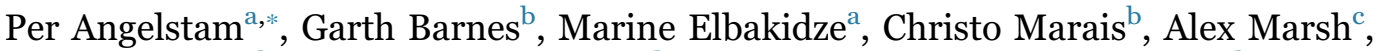 \\ Sarah Polonsky $^{\mathrm{b}}$, David M. Richardson ${ }^{\mathrm{d}}$, Nina Rivers ${ }^{\mathrm{e}}$, Ross T. Shackleton ${ }^{\mathrm{d}}$, William Stafford ${ }^{\mathrm{f}}$ \\ a Swedish University of Agricultural Sciences, Faculty of Forest Sciences, School for Forest Management, Forest-Landscape-Society network PO Box 43 SE- \\ 73921 Skinnskatteberg, Sweden \\ b Department of Environmental Affairs, Natural Resource Management Programmes, 14 Loop Street, Cape Town, 8000, South Africa \\ ${ }^{\mathrm{c}}$ South African National Biodiversity Institute, Private Bag x7, Claremont 7735, South Africa \\ d Centre for Invasion Biology, Department of Botany and Zoology, Stellenbosch University, Matieland 7620, South Africa \\ e Living Lands, 120 Belvedere Road, Claremont 7708, Cape Town, South Africa \\ ${ }^{\mathrm{f}}$ Council for Scientific and Industrial Research, Natural Resources and Environment Unit, P.O. Box 320, Stellenbosch 7599, South Africa
}

\section{A R T I C L E I N F O}

\section{Keywords:}

Ecological (green) infrastructure

Landscape restoration

Active adaptive management

Landscape approach

Learning by evaluation

Scaling-up

\begin{abstract}
A B S T R A C T
Maintenance of functional ecological (or green) infrastructure is threatened by habitat conversion, fragmentation and loss, water scarcity, invasive species, climate change, resource extraction, poor policy implementation and societal inequity. Using South Africa as a case study, our transdisciplinary team identified actions likely to be effective in scaling up research and development projects that support implementation of policy about ecological infrastructure by active adaptive management. Based on expert knowledge at three scales, we analysed South Africa's opportunity to active adaptive management and to unlock investments that enhance functional ecological infrastructure. Barriers included lack of trust among actors, limited collaborative governance and integrated planning, including local partnerships; as well as a poor inclusion of evidencebased knowledge based on monitoring of landscape restoration efforts and its social and ecological consequences. Bridges include practicing transdisciplinary knowledge production, enhancing social learning among actors and stakeholders, and advocacy based on improved understanding. We propose a portfolio of place-based actions that could help to facilitate unlocking investments for functional ecological infrastructure by prioritising conservation, management and restoration through integrated cross-scale, collaborative and multisector spatial planning. Understanding the structure and dynamics of social-ecological systems, identifying champions, framing key messages for different audiences, and sharing failures and success stories internationally, are crucial requirements to unlock investments.
\end{abstract}

\section{Introduction}

The natural capital provided by ecosystems is the ultimate foundation for human well-being. With its unique ability to modify its environment, Homo sapiens is a keystone species - a species that has disproportionately large effects on its environment relative to its abundance. This insight emerged long ago and has led to taboos and ancient norms, medieval legislations and scientific publications over more than three centuries to encourage conservation of natural capital (e.g., von Carlowitz, 1713; Marsh, 1864; Odum, 1959). Nevertheless, the human footprint on this natural capital is still heavy.

To describe the state and trends of ecosystems effectively, their composition, structure and function need to be understood. This complexity is captured by the biodiversity concept (e.g., Noss, 1990), which was originally proposed to highlight the intrinsic value of natural capital. In parallel, contemporary policies aimed at regulating anthro-

\footnotetext{
${ }^{2}$ Revised MS for Special Issue "Developing an Ecological Infrastructure and Ecosystem Services Sector in South Africa" for the journal Ecosystem Services http://www.journals. elsevier.com/ecosystem-services/

* Corresponding author.

E-mail addresses: per.angelstam@slu.se (P. Angelstam), GBarnes@environment.gov.za (G. Barnes), marine.elbakidze@slu.se (M. Elbakidze), cmarais@environment.gov.za (C. Marais), a.marsh@sanbi.org.za (A. Marsh), spolonsky@environment.gov.za (S. Polonsky), rich@sun.ac.za (D.M. Richardson), nina.rivers@gmail.com (N. Rivers), rosss@sun.ac.za (R.T. Shackleton), wstafford@csir.co.za (W. Stafford).
} 
pogenic pressures on ecosystems have adopted the concept of ecosystem services as a metaphor and means of advocacy (MEA (MEA (Millennium Ecosystem Assessment)) (2005)). The ecosystem services concept has launched a large and expanding field of research which seeks to measure and value human and societal dependence on ecosystems (e.g., Norgaard, 2010). Whereas the biodiversity concept captures the potential supply of ecosystem services in terms of what can be derived from species, structures and processes (e.g., Brumelis et al., 2011), the ecosystem services concept focuses on the benefits to human well-being in terms of provisioning, regulating, supporting/ habitat and cultural dimensions (MEA (MEA (Millennium Ecosystem Assessment)), 2005). However, this link is not always straightforward as ecosystems may also incur dis-services; and there are trade-offs among services, stakeholders at different governance levels and spatial scales (Shackleton et al., 2016a; Vaz et al., 2017). Also, abiotic resources need to be considered and human investment is often required to realise the potential of biodiversity components to deliver human benefits (e.g., Lele et al., 2013).

Global or continental assessments of biodiversity and ecosystem services are crucial high-level advocacy tools (e.g., Costanza et al., 1997; Daily, 1997; Sutton and Costanza, 2002; de Groot et al., 2012). In tandem, however, local and regional level place-based approaches are also needed to facilitate appropriate landscape stewardship, strategic planning and land management to maintain functional networks of representative ecosystems that deliver ecosystem services at multiple levels (e.g., Mirtl et al., 2013, Angelstam and Elbakidze, 2017). This is explicitly captured by ecological (SANBI, 2014) and green infrastructure policy (European Commission, 2013), and implicitly by the United Nations sustainable development goals (Mbow et al., 2015). Implementation in places and regions require comprehensive understanding of coupled ecological and social systems (e.g., Angelstam et al., 2013b, 2013c). This process, termed landscape approach (Axelsson et al., 2011; Sayer et al., 2013; Sabogal et al., 2015), is a way of practicing sustainability science (Kates, 2011) in social-ecological systems that includes both evidence-based knowledge and engages multiple and diverse stakeholder groups.

Regarding the ecological system, the transformation of naturally dynamic or authentic cultural landscapes to intensively managed landscapes involves three different interacting factors that affect the functionality of ecological infrastructure: (1) habitat loss, i.e., the amount of land cover patches, which includes (a) the quality of patches, (b) the size of patches and (c) the number of patches (e.g., Fahrig, 2001); (2) fragmentation, i.e. the spatial configuration of patches, (e.g., Fahrig, 2002, 2003); and (3) connectivity, i.e. how the network of patches and the permeability of the matrix surrounding interact with and affect a particular species or process (e.g., Saura et al., 2011; Tischendorf and Fahrig, 2000). Integrated spatial planning to maintain functional ecological infrastructure of representative land covers (i.e. biophysical systems under different land uses) is the foundation for sustaining ecosystem services. This requires not only knowledge about desired benchmark conditions, land cover data and planning tools, but also engagement of stakeholders representing public, private and civil sectors at multiple levels (Elbakidze et al., 2010). Therefore, analysis of the social system is also needed. This include stakeholders' understanding of the issues, their ability and willingness to act (Lundquist, 1987), the establishment of trust and trustworthiness (Hardin, 2002), an understanding of different power relations at play, as well as managing expectations as to who benefits under different scenarios (e.g., Kosoy and Corbera, 2010). For example, operationalisation of strategic integrated spatial plans may be threatened by socio-ecological challenges such as rapidly growing human populations, non-sustainable exploitation of natural capital, and ecosystem degradation as a result of widespread plant invasions, climate change, water scarcity, social inequity, conflicts of interests among stakeholders, corruption and a narrow economic focus (e.g., de Groot et al., 2010; Hoffman and Todd, 2000).
The aim of this paper is to identify ways of bridging barriers in socialecological systems towards collaborative learning, scaling up and unlocking investments for the maintenance of representative and functional ecological infrastructure at different spatial scales. Our team of sustainability scientists, practitioners and public sector experts at different levels of governance collaboratively went through three steps, which are reported in this paper. First, we present three case studies representing the need for investments in ecological infrastructure at national, regional and local levels in South Africa. Second, we identify barriers and potential solutions in the form of knowledge and collaborative learning at multiple levels as bridges within different parts of the social-ecological system. Third, we present a practical portfolio of steps to guide the development of a transdisciplinary culture of knowledge production based on collaborative learning and actions to scaling-up at multiple levels towards unlocking funding and managing investments. Finally, we discuss the need to encourage transdisciplinarity and international collaboration towards functional ecological infrastructure.

\section{Methodology}

\subsection{South Africa as a case study}

South Africa is a global biodiversity hotspot with a wide range of biomes that are subject to large-scale transformation via multiple anthropogenic agents and climate change (Olson and Dinerstein, 2002; Wynberg, 2002; Cowling et al., 2003; Gasparatos et al., 2016). The country also faces major developmental challenges to provide a 'safe and healthy environment' for its people (Shackleton et al., 2017a). The political history of South Africa, and in particular the huge disruptions to the social fabric of the nation caused by apartheid has left a polarised society - despite more than two decades of efforts towards poverty alleviation and other forms of social upliftment (e.g., Bond, 2000; Meredith, 2005). At the same time, South Africa has developed progressive and innovative environmental policies to maintain ecological infrastructure through participatory approaches to protection, management and restoration of ecosystems (Bennett and Kruger, 2015). Examples of this legislation are the invasive alien species regulations of the National Environmental Management: Biodiversity Act and the National Veld and Forest Fire Act. However, despite laudable environmental policies and investments into ecological infrastructure, South Africa is facing challenges with environmental degradation including loss of biodiversity and natural capital, while the government is simultaneously struggling to meet the rapidly increasing demand for ecosystem service delivery. The country is also struggling to turn legislation into effective practices but there is limited capacity to enforce laws (van Wilgen et al., 2016a). This calls for increased and improved relevance and coherence of investment portfolios to ensure the delivery of ecosystem services. Unlocking public and private sector funding for restoration of degraded ecosystems (Mills et al., 2015) is crucial as well as to ensure the sustainability of investments into functional ecological infrastructure through collaborative learning based on active adaptive management (e.g., Shea et al., 2002). South Africa is thus an excellent case study for elucidating the issues that confront actors at multiple levels involved with governance, management and assessment (Blignaut et al., 2013, 2014).

\subsection{Atelier approach}

This study emerged from an atelier workshop (Farley et al., 2005) held by the Ecosystem Services Partnership at St Helena Bay in South Africa during November of 2015. The aim of the workshop was to build the case for further investment in natural resource management (NRM) to develop a functional ecological infrastructure in South Africa. Specifically, the workshop aimed to: i) analyse barriers and bridges for improving investment in NRM; ii) analyse the need for integrative knowledge production and learning for optimising and unlocking investment in ecological infrastructure and; iii) understand 
Table 1

Roles represented by the co-authors of the transdisciplinary author collective.

\begin{tabular}{lllll}
\hline & $\begin{array}{l}\text { Civil } \\
\text { sector }\end{array}$ & $\begin{array}{l}\text { Private } \\
\text { sector }\end{array}$ & $\begin{array}{l}\text { Public } \\
\text { sector }\end{array}$ & Academia \\
\hline $\begin{array}{l}\text { International level } \\
\text { National level in South } \\
\text { Africa } \\
\text { Regional level in South }\end{array}$ & $\mathrm{x}$ & $\mathrm{x}$ & $\mathrm{xxx}$ & $\mathrm{xx}$ \\
$\quad \begin{array}{c}\text { Africa } \\
\text { Local level in South Africa }\end{array}$ & $\mathrm{x}$ & $\mathrm{x}$ & $\mathrm{x}$ & $\mathrm{xx}$ \\
\hline
\end{tabular}

how valuing ecosystem services can contribute to unlocking investments. Participants were invited based on their areas of relevant academic and non-academic experience and knowledge to ensure representation across a diverse range of backgrounds. The workshop involved 44 South African and international participants with a range of often overlapping backgrounds, representing government policy makers and managers (21), researchers from a variety of natural and social science disciplines (20), and representatives from the media (4), private sector (4) and various NGOs (6). The participants were engaged in the workshop through break-out groups and plenary discussions, which resulted in several teams aimed at reviewing knowledge and experiences in a particular topic (e.g., Shackleton et al., 2017a).

The authors of this paper had a common interest in diagnosing and treating social-ecological systems in the context of implementing policy about ecological infrastructure at different spatial scales and levels of governance. Each author brought their own expertise (Table 1) and knowledge which were compiled, analysed and synthesised through face-to-face group discussions and a post-workshop writing process. This paper is thus an outcome of a transdisciplinary process which integrates academic and non-academic participants' production of new knowledge through a collaborative learning process (see Hirsch Hadorn et al., 2008). This is manifested by including both narrative texts and research reviews (e.g. Axelsson et al., 2013a).

Using our national and international experiences from research, policy and practices of governance, management and monitoring, we carried out three processes to identify the main barriers and bridges for implementation of functional ecological infrastructure. Firstly, three case studies were chosen to represent national, regional and local levels of policy implementation for improving the functioning of ecological infrastructure in South Africa. The authors agreed that these examples reflect the existing key challenges in policy implementation at different levels in the country. Secondly, using the unique opportunity for academic and non-academic experts to work together, barriers and bridges were extracted from the narrative case studies for how adaptive management could be approached actively by combining "ecological intervention with a plan for learning about the system" (e.g., Shea et al., 2002). Inspired by Moser and Ekstrom (2010) we developed a simple active adaptive management cycle. In spite of the real world being iterative and messy, for convenience we depict this cycle as linear (Fig. 1, Table 2). The "architecture" is based on (i) the initial policy objective, (ii) the steering actors at multiple levels of governance, (iii) being managed-oriented; and (iv) focus on assessment by comparing consequences in social and ecological systems with norms linked to the policy objective (Fig. 1). For each of the four steps both barriers, defined as obstacles that can be overcome, and bridges, defined as how barriers can be overcome, were listed. Thirdly, we compiled a generally applicable portfolio of actions to support implementation of policy on ecological infrastructure in social-ecological systems. The objective of this portfolio is to support development of a culture of transdisciplinary knowledge production through collaborative learning, actions at multiple levels to scale up research and development projects, and unlock funding for investments in ecological infrastructure as well as governance, management and follow-up.

\section{Examples at national, regional and local levels}

\subsection{Natural Resources Management programmes in South Africa}

South Africa's Department of Environmental Affairs (DEA) is tackling the challenge of natural resource management, environmental protection and infrastructure through the multi-faceted Natural Resources Management (NRM) and Environmental Protection and Infrastructure (EPI) programmes. The NRM programmes (NRM programmes, 2017) address threats from invasive alien species, wildfire and habitat loss to land degradation to the productive use of land and water and the functioning of natural systems. This work helps to ensure benefit to livelihoods through employment in marginalised communities and development opportunities for value-added products, particularly in rural areas. In essence, these programmes aim to restore and maintain natural resources to ensure the delivery of ecosystem services that are essential for human well-being and socio-economic development. In doing this work, these programmes will help to fulfil the Department Environmental Affairs' core vision: 'a prosperous and equitable society living in harmony with our natural resources'.

These NRM programmes, popularly referred to as the "Working for..." initiatives, have succeeded in mainstreaming ecological restoration into the employment and rural development sectors (e.g., van Wilgen and Wannenburgh, 2016; Fig. 2). They contribute primarily to unemployment, rural development and improving water security as well as help to fulfil DEA's core vision (DEA (Department of Environmental Affairs), 2013). Launched in 1995, the Working for Water (WfW) programme was a multi-departmental programme. WfW aims to prevent, contain and reduce the density and distribution of established, invasive alien species to reduce their negative effects on the environment. Initially, the primary focus of WfW was on the management of invasive species known to have negative impacts on stream flow. However, it was soon realised that WfW cannot operate in isolation. For example, when invasive alien plants are cleared from riparian zones and wetlands there may still be an imperative for the restoration of the cleared area to improve water purification and retention and ultimately to improve dry season flows. The WfW programme's annual budget has grown from R25 million in 1995 to R1.8 billion in 2015. Significant progress has been made in the clearing of invasive alien plants and the NRM programmes have been expanded to include also fire, forests, value-added industries, ecosystems, wetlands, energy, and biosecurity. In addition to restoring natural capital, these programmes provided between 5000 and 1500 jobs per annum for the most marginalised people in society since its inception in 1995. To date 2.8 million hectares of invasive alien plants have been treated (invasive alien plants cover approximately twenty million hectares of South Africa). Although WfW has made progress, research has shown that invasive alien plants might be spreading faster than the rate of clearing. It has been estimated that the spread may be between $7.4 \%$ and $15.6 \%$ (depending upon species), while current control effort may only be reducing the spread by $1 \%$. This indicates that a triage approach is needed in terms of achieving local reductions priority areas, substantial upscaling, and additional investments to reduce the total spread of plant invasions (van Wilgen et al., 2012, 2016b). However, recent research has also revealed the inefficiency of some WfW initiatives that acts as a major barrier to effective use of limited funds (Shackleton et al., 2016b; van Wilgen et al., 2016b). There are other effective control strategies aside from manual control efforts including increased mechanisation of clearing, the application of biological control and various pre-, at- and post- border biosecurity measures.

In 2004, the Working for Wetlands (WfWet) programme, initially run as a sub-programme of WfW, was formally established. The aim was to prevent and reduce the degradation of wetlands through rehabilitation methods with ecological and engineered infrastructure to restore hydrological function that underpins water flow and quality 


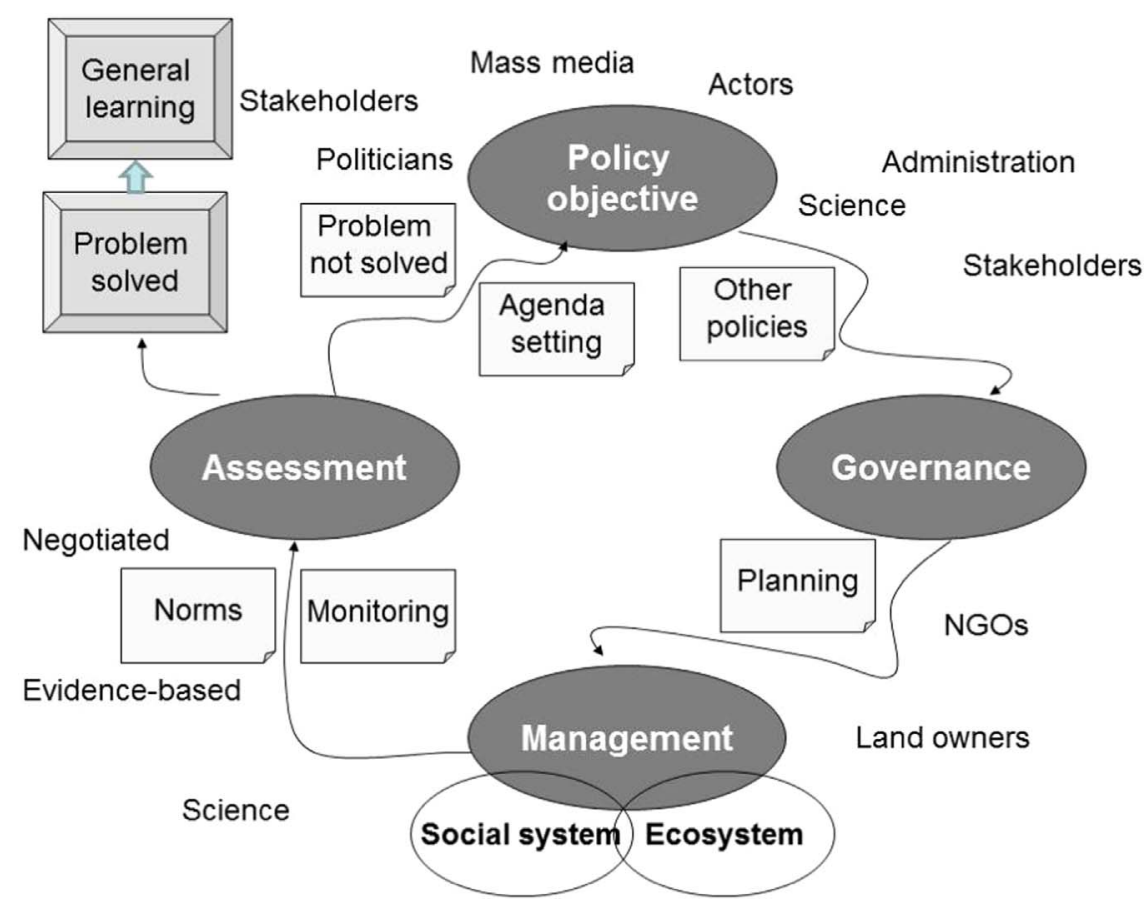

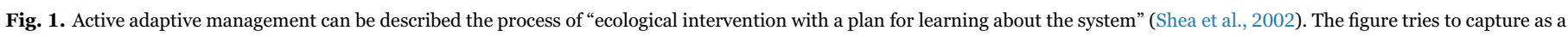

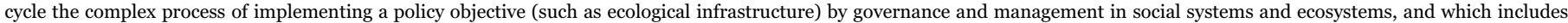
assessment of the consequences both in the specific place or region, as well as encourages general learning.

regulation. To date, WfWet has invested in the restoration of 970 wetlands. Despite this large number, significantly more investment in wetland restoration is needed country-wide to improve water quality and retention for improving dry season flows.

The recognition that devastating wild fires across South Africa were associated with high fuel loads from dense stands of invasive alien plants initiated the Ukuvuka Campaign in 2000, and this led to the establishment of the national Working on Fire (WoF) programme in 2004 (Fowkes, 2007). WoF aims to develop a national, integrated approach to veld and forest fire management to enhance the protection of life, livelihoods, assets, ecosystem services and natural processes.

The Subtropical Thicket Restoration Programme (STRP) was also established in 2004 to develop a scientific platform for catalysing public and private sector investment in the restoration of more than one million hectares of degraded subtropical thicket in the Eastern Cape of South Africa (Mills et al., 2007). This project morphed into Working for Ecosystems (WfEco) and was expanded to the grasslands and savanna areas of the Maloti-Drakensberg in the northern parts of the Eastern Cape, KwaZulu-Natal and the other northern provinces. WfEco aims to restore natural habitat composition, structure and function, thereby improving the delivery of key ecosystem services including carbon sequestration, water regulation and purification, and reducing the risk of natural disasters by improving landscape/catchment stability and resilience To date, WfEco has nearly 22,000 ha of land under restoration for the improvement of watershed services, sequestering carbon, improving the productive potential of the land, and improving biodiversity. The Working on Fire (WoF) programme aims to develop a national, integrated approach to veld and forest fire management to enhance the protection of life, livelihoods, assets, ecosystem services and natural processes.

Recent additions to the suite of NRM programmes include Working for Forests (WfF) and Value added Industries (VAI). WfF aims to improve the management of South Africa's forests and plantations to reduce the risks of invasions, increase biodiversity and deliver socioeconomic benefits. The VAI programme creates work opportunities and delivers socio-economic benefits through the optimal use of cleared invasive alien plants. Current projects produce "eco-furniture" such as school desks for under-resourced schools through a contract with the
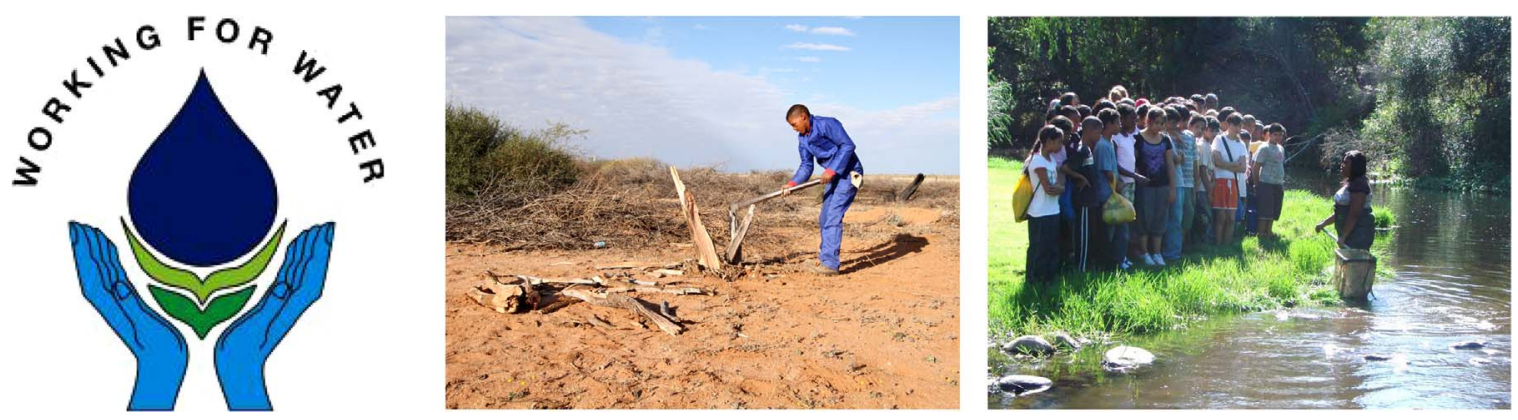

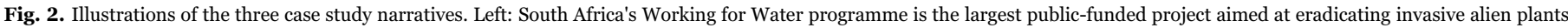

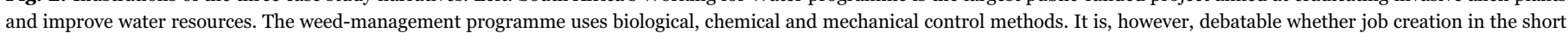

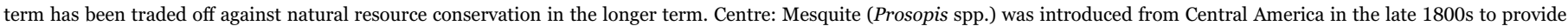

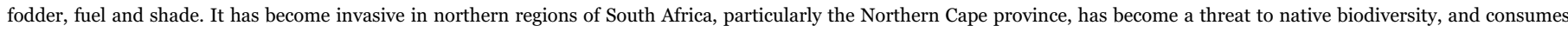

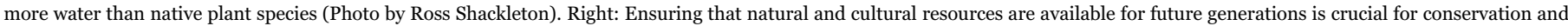

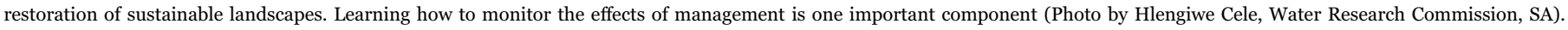


national Department of Basic Education. Harvesting of some invasive tree species for fuelwood in accessible areas, in tandem with the impacts of biocontrol, is starting to have an impact on the extent of invasive plants. This happens largely independent from Working for Water. Furthermore, the recent establishment of the Biosecurity directorate of DEA aims to give effect to the national environmental regulations on invasive species (NEM: BA) and covers the full scope of strategic interventions by using an integrated approach of risk assessment, surveillance, early detection and eradication.

\subsection{Management of mesquite (Prosopis) invasions in the Northern} Cape

Prosopis is the second most widespread invasive plant genus in South Africa after Australian acacias (van Wilgen et al., 2012). Several species of Prosopis and their hybrids (hereafter "mesquite") have invaded large parts of the arid interior of the country, predominantly in the Northern Cape province (Fig. 2). Mesquite was introduced from Central America during the late 1800s to provide fodder, fuelwood and shade to local communities. However, invasive stands of mesquite have major negative impacts on biodiversity, water, local economies and human well-being (Shackleton et al., 2015, 2017b). Well established stands become impenetrable and therefore inaccessible for fodder. Besides these land-use and biodiversity impacts, a recent study showed that dense stands of mesquite use four times more water than indigenous trees in non-degraded/intact habitats (Dzikiti et al., 2013). The costs associated with invasive mesquite now outweigh the benefits, highlighting the need for innovation in management (Wise et al., 2012; Shackleton et al., 2015, 2017b). Although WfW spent R 1 billion (US \$ 74 million) between 1996 and 2015 on managing mesquite, invasions continue to spread rapidly and have expanded from approximately 1.8 million ha to an estimated 6-8 million ha in this time frame (Shackleton et al., 2017b). The rapid spread of mesquite, and inefficiency in managing the problem, indicates substantial management barriers both on private and state land (Shackleton et al., 2015, 2016b, 2017b).

\subsection{Collaborative planning in a local community}

Considering ecosystem services at a local level, we use the collaborative work of a local not-for-profit organisation (NGO) with stakeholders around a wetland as a case example at the local level. Since 2015, an NGO called Living Lands (https://livinglands.co.za/) has been engaging and building relationships with peri-urban communities in the Western Cape around the development of a derelict recreational park and the protection of a nearby wetland and nature reserve in two communities near Stellenbosch. Living Lands engages with the local government, commercial land owners, nature conservation agencies and the tourism board in the area to facilitate a process for all the different stakeholders involved to develop a collaborative plan for these areas (Fig. 2).

The men in these communities previously worked mainly in the forestry and sawmill industries, but many lost their jobs when forestry operations in the region ceased. Compensation was promised to individuals, which they argue they are still waiting for. As a result, the community feels hard done by in terms of developments and broader initiatives in the area. When the forestry operations closed, one of the communities claimed that the park and wetland was given to them as compensation for job losses. Although they do not claim ownership of the park, residents of the other communities feel they should also be included in and benefit from developments in the park which was previously a popular destination for recreation. When the management and ownership of the park became unclear, it fell into disrepair and it has allegedly become a source of fires that threaten neighbouring wine farms. During conversations and workshops with Living Lands, lack of trust was evident among stakeholders as they blamed each other for the current state of disrepair of the park. A wetland of great ecological value in the park has been fragmented by roads and train tracks, and part of the wetland is no longer being maintained. This brief sketch illustrates the complexities (economic, social, political and ecological) involved in engaging with communities regarding the park and wetland. Communities understand the ecological and potential economic value of the park and wetland and both would like to see something develop there. The challenge is to devise protocols for collaboration to this end.

\section{Barriers and bridges at multiple levels}

\subsection{National level}

Given the scale of the problems faced in the "Working for..." programmes, coupled with the constraints on resources available to invest in addressing the challenges, a need was identified to increase the efficiencies and effectiveness of the programmes - in terms of management, planning and evidence-based follow-up that could aid decision-making and provide operational support to programme implementation (Table 2). Some of the barriers identified include a tension that exists between the social and environmental priorities within the managers and implementers of the NRM programmes. Due to the nature of the funding which is aimed at poverty relief, budget and capacity constraints, insufficient emphasis has been given to research and the need to understand the social dynamics at play in communities in which NRM works. A major problem is the indicators that are applied in gauging progress; these typically focus largely or exclusively on metrics such as the number persons employed to do the work, rather than on metrics linked to the problems that the programmes are addressing. More attention should be given to understanding the outcomes and impacts of NRM programmes, in terms of enhancing ecosystem services and ensuring that these benefits are delivered equitably to society. For example, monitoring of and reporting on water flows at appropriate scales following restoration from the clearing of invasive alien plants is needed. This would allow for the tailoring of benefits to improve community livelihoods and socioeconomic development. Another notable barrier is insufficiency in the diversity and scale of investments into ecological infrastructure for delivery of ecosystem services. While managing plant invasions in the most cost-effective way, NRM managers are grappling with the question of how to deliver on the key performance criteria of job creation. The lack of broad-based, effective partnerships between the public and private sector can be seen as a barrier, but also an opportunity for the state to develop new business models, enterprises and solutions. NRM programmes have a broad environmental mandate with an enormous burden of both previous and ongoing loss and degradation of ecosystems. Therefore, there is a need to optimise investments through effective partnerships between government, private sector and civil society at multiple scales. Such partnerships will improve stakeholder engagement and co-ordination in the planning of investments to improve the accountability, and reduce the inefficiencies by "working together" instead of "working in silos", and thereby work towards a common goal. Improving the governance in the NRM programmes through broad stakeholder engagement, effective partnerships, and co-ordinated investments will improve investor confidence and facilitate the catalytic funding needed to upscale the NRM programmes. In South Africa, as elsewhere in the world, government employees (natural resource managers) are often overwhelmed with bureaucracy. There is a need to move and adapt with the change within bureaucratic constraints.

Given the challenges facing the implementation of effective natural resource management in South Africa there is a need to integrate management, planning and research that could aid evidence-based decision-making. To increase the efficiencies and effectiveness of the NRM programmes the avenue identified was to develop a "NRM 
Table 2

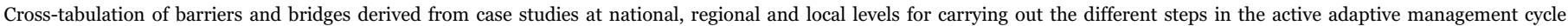
(Fig. 1) towards functional and representative types of ecological infrastructure in South Africa.

\begin{tabular}{|c|c|c|}
\hline & Barriers & Bridges \\
\hline Objective & $\begin{array}{l}\text { - Policy implementation instruments (whip, carrot, sermon) aimed } \\
\text { at maintaining ecological infrastructure are not well developed } \\
\text { - Different policies are in conflict with each other } \\
\text { - Limited support for transdisciplinary knowledge production and } \\
\text { collaborative learning }\end{array}$ & $\begin{array}{l}\text { - Valuation of ecosystem services using multiple methods } \\
\text { - Legislation should require reporting of the state of invasive species on your land } \\
\text { - Maximise adherence to legislation and increase voluntary compliance } \\
\text { - Advocacy for land-user incentive scheme scaled up } \\
\text { - Unlocking of further budgets needed }\end{array}$ \\
\hline Governance & $\begin{array}{l}\text { - Failure to adopt recommendations from scientific research and to } \\
\text { implement them at all levels of management } \\
\text { - Inflexible bureaucratic programmes and projects make active } \\
\text { adaptive management difficult } \\
\text { - Insufficient focus on social dynamic in governance } \\
\text { - Communication gaps between tiers, areas, levels } \\
\text { - Sectoral silos create duplication and can lead to a lack of informed } \\
\text { decision making }\end{array}$ & $\begin{array}{l}\text { - The creation of platforms where successes can be showcased } \\
\text { - Improved partnerships at local, regional and national levels that are supported by } \\
\text { transdisciplinary knowledge and learning } \\
\text { - Improved communication and information sharing } \\
\text { - Promoting broad participation and engagement } \\
\text { - Enabling environment for transformative social learning through deconstruction (de- } \\
\text { framing) and re-construction (re-framing). }\end{array}$ \\
\hline Management & $\begin{array}{l}\text { - Inefficient planning and management } \\
\text { - Focus on short-term social consequence at the expense long-term } \\
\text { ecological consequences } \\
\text { - Limited investment into the natural resource management sector }\end{array}$ & $\begin{array}{l}\text { - Scale up demonstration and research projects } \\
\text { - Develop skills in management of large management projects } \\
\text { - Link investments in ecological infrastructure to climate change adaptation and } \\
\text { disaster risk reduction } \\
\text { - Develop compelling business models to attract buy in by land users } \\
\text { - Innovation and capacitation in small and middle-size enterprises to participate }\end{array}$ \\
\hline Assessment & $\begin{array}{l}\text { - Investment in learning is poorly developed } \\
\text { - Limited efforts to systematically assess effectiveness in governance } \\
\text { and management } \\
\text { - Unbalanced monitoring of management consequences favouring } \\
\text { social system over ecological system }\end{array}$ & $\begin{array}{l}\text { Monitoring and evaluation of both social and ecological consequences of managing } \\
\text { ecosystems according to agreed objectives } \\
\text { - Focus on continuous improvement with real numbers being produced to show impact } \\
\text { and results } \\
\text { - Provide evidence-based knowledge to guide investment decisions } \\
\text { - Loose silos and start working together (collaboration with other projects in the } \\
\text { geographical area of work and share budgets, outputs, resources and knowledge), } \\
\text { strengthening of partnerships and the creation of spaces to share successes and } \\
\text { challenges }\end{array}$ \\
\hline
\end{tabular}

community of practice" that brings together MAnagement, REsearch and Planning (MAREP) personnel. MAREP was inspired by meetings of managers and planners from regional offices and scientists from research centres conducted by the South African Department of Forestry in the 1970s and 1980s (van Wilgen et al., 2016a). The goal was information sharing and engagement around common problems. This atelier approach (Farley et al., 2005) is aimed at senior managers and partners within the NRM programmes to share lessons and knowledge around evidence-based decision making, and to develop strategic foci for the programmes going forward. The goals of MAREP in its new iteration in the NRM context are to:

- Facilitate feedback between managers and implementers, researchers and planners to ensure that decision making is being informed by all facets of the network;

- Facilitate ongoing dialogue and positively influence how both research and implementation are conducted;

- Influence organisational culture within Department of Environmental Affairs and the NRM sector in a manner that encourages increased cross-sectoral engagement and reduces duplication of efforts;

- Provide spaces where innovative ideas can be discussed, and complex challenges addressed in a critical and solution-driven manner.

Central to the goal of this community of practice is to ensure that managers, researchers and planners working within the NRM Programmes are communicating and collaborating effectively, developing responsive and dynamic partnerships, and meeting the needs of their programme of work. Several MAREP workshops have been convened to provide a space to reflect on key topics of concern for the programme on different levels and scales: from national, regional and local, to strategic and thematic.

\subsection{Regional level}

Prosopis (mesquite) has invaded the drier, northern regions of South Africa, particularly the Northern Cape province. A combination of low human population densities and a high level of poverty in these areas, together with the fact that these areas were not surveyed as part of the National Invasive Alien Plant survey (Kotzé et al., 2010), has led to high levels of invasion. The focus on measuring social benefits and outcomes rather than ecological ones allowed Prosopis invasions to increase without alarm being raised until they reached an unmanageable state. This barrier indicates the need to improve ecological monitoring and early detection and response (Wilson et al., 2013; Shackleton et al., 2016b, 2017a). Bridging this gap in monitoring and reporting about the state of ecosystems can enable cost savings from early detection and response, but will require broad participation from government and civil society.

A systematic analysis of perceptions relating to the barriers to the effective management of mesquite revealed $>100$ unique issues (Shackleton et al., 2016b). The most prominent barriers included: the lack of strategic planning and prioritisation; lack of partnerships and communication between stakeholders; inadequate local supervision and management; inefficiencies relating to the temporal time frames of the projects; lack of knowledge and awareness of existing knowledge; and conflicts of interest relating to the benefits vs. the costs of mesquite and different management options available. There were marked differences between stakeholders regarding the importance of some of these barriers, reflecting very different views about the context in which mesquite control and management projects operate. For example, most farmers ( $>80 \%$ ) viewed a lack of planning and poor management as important barriers, whereas relatively few managers $(<20 \%)$ regarded these as important. This is in alignment with regulations of the National Environmental Management: Biodiversity Act that stipulates that detailed management plans are required for all major invasive taxa. However, operationalising these plans seems less clear.

The creation of jobs to alleviate poverty, particularly in rural areas of South Africa, has acted as a motivation for investment from the government's Expanded Public Works Programme (EPWP). However, there is still a lack of co-ordinated investment and implementation of $\mathrm{NRM}$, and there is a need for more participation from the private sector (Shackleton et al., 2017a). The "Working for...” programmes have been 


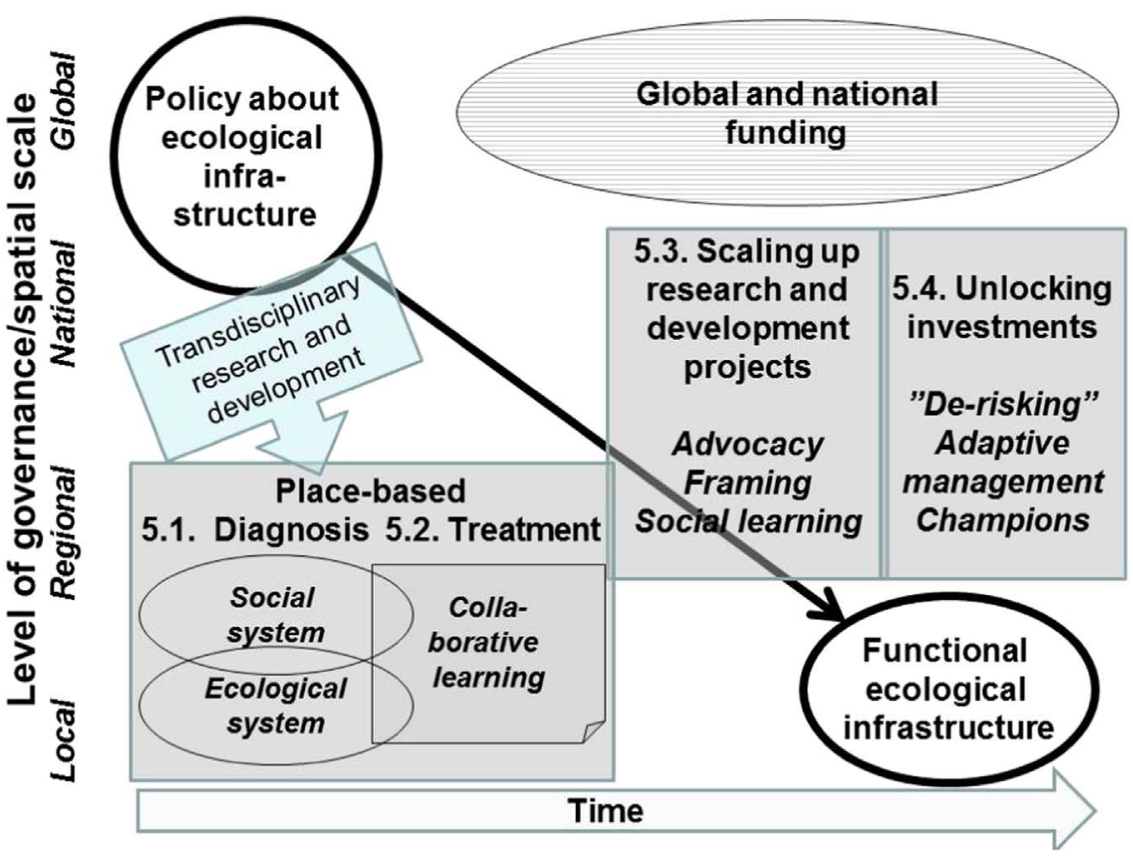

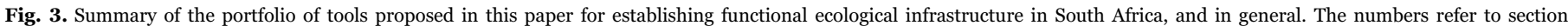
headings in the text.

highly beneficial for providing employment opportunities and a practical skill set for thousands of unskilled labourers (Giordano et al., 2012), but there are still capacity issues at project and middle management levels (Shackleton et al., 2016b). The need to report on job creation for EPWP funding has sometimes resulted in failure to report on environmental outputs and outcomes (van Wilgen and Wannenburgh, 2016), and there is currently limited evidence of the benefits from clearing invasive species in terms of the extent of the supply of ecosystem services at the national level (van Wilgen and Wannenburgh, 2016; Shackleton et al., 2017b). This can largely be ascribed to the cost and resource needs of monitoring and sectors' inability to develop "trustworthy" models to extrapolate outcomes of local interventions in terms of downstream, regional and national impacts. Based on the identification of barriers, numerous recommendations have been highlighted in a preliminary strategic plan to optimise investment in natural resource management. These recommendations include filling in certain knowledge gaps, enforcing legislation better, improved monitoring, and improvements in communication and collaboration (Shackleton et al., 2017a).

\subsection{Local level}

The Western Cape case study highlights several key barriers to valuing and managing ecosystem services at the local level. These include issues of ownership, socio-economic realities, lack of trust among stakeholders, the lack of skills to access funds and information and the quality of stakeholder engagement. Ownership and perceptions regarding value of the wetland are clearly fundamental barriers in the two communities discussed in this case study. It is difficult for people to take responsibility for something that they do not own or for which they see no clear value. This is linked to how different stakeholders value ecosystem services, which often hinges on their understanding of the value of different ecosystems. Some residents say they have attended workshops explaining the value of wetlands, but that their perceptions are tempered by socio-economic realities and more urgent needs, such as lack of adequate housing, unemployment, and the search for economic opportunities. Some residents expressed the desire to build houses or to develop agricultural enterprises on the land to create jobs in their communities. Capacity to manage the wetland is also limited as local conservation agencies are unable to commit to managing areas for which resources are not available to implement sustainable management programmes.

This case study highlights the complexity inherent in valuing and managing ecosystem services from the perspective of South Africa's broader socio-ecological history and context. The legacy of apartheid is still evident in the racially segregated communities in many areas where social and economic inequity is pronounced. The closure of forestry and sawmill operations in the area has also seriously reduced economic prospects. Youth unemployment is high as are high school failure and drop-out rates. Additionally, relations between communities, government agencies, local municipalities and private businesses are often strained and characterised by distrust. This situation does engender an ethos of "working together" to value natural capital and seek ways of managing degraded ecosystems. Yet another challenge is that disenfranchised communities often lack the skills and knowledge required to access funds and relevant information.

From a social-science perspective, the move towards any sustainable commitment for the protection, management and restoration of South Africa's ecosystems requires sincere engagement with stakeholders. Poor stakeholder engagement is therefore very often a fundamental barrier to valuing ecosystems (Cowling et al., 2008), and requires commitment of time from all stakeholders to understand the issues at hand and to take ownership of the actions needed. Establishing stakeholder engagement processes to build trust and partnerships between people, communities and government can provide a bridge to help to overcome these barriers.

\section{A portfolio of tasks towards functional ecological infrastructure}

\subsection{Place-based "diagnoses" of social-ecological systems}

\subsubsection{Analyses of functionality of ecological infrastructures}

A key starting point for optimising investment in landscape restoration towards a functional ecological infrastructure is to understand what this really means. This requires knowledge about benchmark conditions such as evidence-based performance targets for species, structures and processes, i.e. biodiversity, as base for delivery 
of ecosystem services in a concrete area (e.g., Balmford, 2003; Pressey et al., 2003) (Fig. 3). Improving the understanding of functional ecological infrastructure may involve the following steps (e.g., Angelstam et al., 2004; Villard and Jonsson, 2009): (1) Stratifying the focal area into representative land cover types in terms of natural potential vegetation, or desired cultural landscapes; (2) Describing benchmark conditions in terms of historical range of variability using biodiversity components, and when relevant biodiversity intactness or levels of naturalness (Peterken, 1996); (3) Identifying response variables expressed in terms of the desired ecosystem services, which are affected by demand and anthropogenic pressures; (4) For each type identified in step 1, combining steps 2 and 3 to test for the presence of non-linear responses and identify zones of uncertainty; (5) Identifying the "currencies" (i.e. expressed as biodiversity components or ecosystem services) which are relevant and possible to communicate to stakeholders.

Next, the relative impact of habitat loss, fragmentation and connectivity of land cover patches on the state of biodiversity needs to be assessed to determine the value of ecosystems from an ecosystem services perspective. Data about the current state and trend of representative land cover patches can be used in systematic strategic, tactical and operational planning. For example, gap analysis can be used to estimate how much of different habitats remain in different regions compared to the historical range of variability. This can be complemented with evidence-based knowledge about how much habitat loss that can be accepted without losing species (Angelstam et al., 2011a; Margules and Pressey, 2000; Groves et al., 2002; Svancara et al., 2005; Tear et al., 2005). For example, application of gap analysis for strategic planning in Sweden (Angelstam and Andersson, 2001) and Estonia (Lõhmus et al., 2004) was instrumental in providing evidence-based knowledge to the policy level. For example, in Sweden this resulted in the subsequent establishment of approx. 900000 ha of protected areas (e.g., Angelstam et al., 2011a). The functionality of different types of ecological infrastructures can also be evaluated for tactical spatial planning. For example, by carrying out habitat-suitability index modelling using evidence-based knowledge on species' requirements at the point, patch and landscape scales (Angelstam et al., 2004), or by using a virtual species approach (Mikusiński and Edenius, 2006). This can be complemented by quantifying the importance of habitat patches for landscape connectivity (http://www.conefor.org; Saura and Torne, 2009) and identifying a structural connectivity (Vogt et al., 2009). Finally, results of systematic assessments need to be addressed in operational land management activities.

\subsubsection{Analysing the social system}

To understand the link between ecological infrastructure and the benefits that they provide to people and society, it is important to learn about how different actors and stakeholders use, manage and govern landscapes (Angelstam et al., 2003, 2013b) (Fig. 3). This involves several steps. The first is to survey stakeholders across the institutional and geographic landscape (e.g., Elbakidze et al., 2010; Axelsson et al., 2013a). For analyses of governance arrangements these can be grouped according to (i) the sector which they represent (e.g., civil, private or public); (ii) their level of activity (e.g., local; regional; constitutional, and international level, as well as authority). The second is to describe landscapes' use and non-use values, and the products derived from those (c.f. Merlo and Croitoru, 2005). The third is to identify different types of land cover and land use, as well as property and land userights, and how these are linked to different use and non-use values (e.g., Sigwela et al., this issue). To communicate states and trends also social and cultural values need to be understood. This means to identify and use measurable relevant variables that reflect different spatial scales such as local communities or regions (Axelsson et al., 2013b).

Natural resource management and use depends on the societal context. This requires analysis of the system of governance in terms of formal and informal institutions, i.e. rules, norms and policy (e.g., Elbakidze et al., 2013), and levels of collaboration among stakeholders at multiple levels (e.g., Elbakidze et al., 2010). An important factor is to understand the policy objectives and their corresponding ambition levels for sustainability. It is important to note that national policy or other strategy documents specific to the studied local landscapes or regions may differ from international ones. These may thus not be reflected or even shared at a local or regional level. Analysis should thus match the scale of investigation, reflecting the specific challenges, values and opportunities of a particular place-based case study.

In addition to indicators for monitoring social and ecological systems it is necessary to assess whether policy objectives are satisfied or not. This can be done by assessing their states and trends of indicators by comparisons with norms as performance targets. Assessment implies policy implementation studies. This is about what develops between the establishment of a policy objective and the impact of governance and management actions on landscapes and regions. Following Rauschmayer et al. (2009), it is crucial to understand the process of formulating policy objectives, the outcome of this process in terms of outputs as rules and norms for governance and management and finally the consequences on the ground in both ecological and social systems. Three key aspects affecting the opportunity for policy implementation are stakeholders' understanding and knowledge about ecological infrastructure, their willingness to act and their attitudes (Lundquist, 1987).

\subsection{Collaborative learning as "treatment" of a social-ecological system}

The linkages between ecosystems and social systems can be captured as a supply-demand gradient from the capacity of ecosystems to deliver services, to ecosystem services as benefits that satisfy human demands and well-being (Burkhard et al., 2012). Given this complexity and the need for strategically planned networks of representative natural and semi-natural land covers as components of ecological infrastructures, a wide range of stakeholders and actors need to share knowledge to overcome the many barriers.

Based on evidence-based knowledge about the states and trends of ecological infrastructure and the consequences for human wellbeing in social systems, opportunities for collaborative learning among engaged actors and stakeholders represents a bridge to valuing and managing ecosystems (Fig. 3). Collaborative learning is a transdisciplinary approach that originated in the 1990s in the US Pacific Northwest as a means of dealing with complex natural resource management controversies involving many stakeholders with conflicting interests that are difficult to fully understand (Daniels and Walker, 2001). Prerequisites for collaborative learning include a willingness of stakeholders to collaborate (San Martín-Rodríguez et al., 2005), working as equals (Arnstein, 1969; Kabanoff, 1991), respecting each other's opinions, interests and professions (San Martín-Rodríguez et al., 2005), and empowering each other. Collaborative learning is thus a means of identifying a common frame for a complex situation and from this base to define and develop new opportunities by joint learning (Angelstam et al., 2013a).

Practically, collaborative learning includes identification of the collaborative potential among stakeholders, setting up a series of events to promote learning and creative thinking, inputting new knowledge to the process and arranging constructive debates to support stakeholders and their learning. In addition, it also includes the implementation of these ideas, assessment of outcomes and thoughtful reflection (Daniels and Walker, 2001). Dialogue and development of a shared understanding amongst diverse groups of people, sharing perspectives and debating points of view are seen as a key step towards creating more informed, reasoned and consensus-based decisions. Systems thinking, in combination with other participatory methodologies that support broad participation and transdisciplinary 
knowledge, provide a methodical process by which complex problems may be disentangled and better understood in a collaborative-learning context (see Dawson et al., 2017). This facilitates dialogue, knowledge sharing and thereby allows stakeholders to identify, discuss and choose between different strategies to problem solving. Such an approach is often constructive and reduces conflict through broad participation, collaboration, process ownership and group learning (e.g., Sterman, 2000; Fraser et al., 2006).

\subsection{Scaling up research and development projects}

\subsubsection{Social learning}

Collaborative learning does not just happen. An intentional learning approach to natural resource management applies principles and theories of adult, organisational and social learning. According to Keen and Mahanty (2006) this is underpinned by three core elements: systems thinking, negotiation, and reflection. Social learning (Fig. 3) is a process that uncovers what people want to learn, how they learn, how they overcome personal biases and group thinking and how they can become more sensitive to alternative ways of knowing, valuing and doing (Wals, 2007a). Literature on social learning often refers to the bringing together of multiple perspectives, values and interests to creatively work on stubborn practices that lead to unsustainability (Lotz-Sisitka, 2012). This creative process does not happen automatically and social cohesion is one of the key elements needed in order for different actors to work constructively together to find solutions to sustainability challenges by taking part in targeted collaborative learning. While it is true that one definition of social learning positions it as a multi-scale process or "multiparty collaboration processes" (Pahl-Wostl et al., 2007, p. 5), it is equally true that social learning also involves the drawing together of "divergent interests, norms, values and constructions of reality [which] meet in an environment that is conducive to learning...[and] takes place at multiple levels" Wals (2007b). Wals (2007b) definition of social learning supports the notion of a society that engages issues with a plethora of voices that come from many different values and interests in general.

\subsubsection{Framing}

Framing is a process whereby actors construct and represent meaning to understand a particular event, process or occurrence (Goffman, 1974) (Fig. 3). Framing can be used in both strategic ways to enable the achievement of certain goals as well as in interpretive ways to help us make sense of complex situations (Kaufman and Smith, 1999; Gray, 2004; Shmueli et al., 2006; Woodford et al., 2016). However, when framing is founded, instructive past experience (our social constructions) or applied erroneously to present experience, errors in response and management can prevail. Since interpretive frames may be developed and reinforced over decades, changing perceptions or re-framing have require considerable effort. Several types of framing have been identified (Kaufman and Smith, 1999; Shmueli et al., 2006):

- Fixed pie (zero-sum) frames: this type of frame makes it difficult for someone to imagine alternatives that would be beneficial for all parties involved because of our competitive culture which primarily tends to reduce stakeholders to winners and losers.

- Loss/gain frames: this type of frame represents uncertain consequences of a stakeholder's choice as either a loss or a gain. People may tend to work harder to prevent a loss than to capture a commensurate gain.

- Characterisation frames: these frames are labels, associating positive or negative characteristics with individuals or groups of people. They are often stereotypical evaluations of others' behaviour, attitudes, motives or trustworthiness. They develop from direct experience but are reinforced through media and existing beliefs and experience.

- Identity frames: foregrounding oneself or one's own role or own group's role in the conflict in a positive or negative way.
Mutual understanding, and thus re-framing, requires an awareness of other people's frames within a trusted, facilitated dialogue (Wals, $2007 \mathrm{ab}$ ) so that re-framing is facilitated by a process where direct experience or new information manages to overwhelm filters that frame a person's perspective (Kaufman and Smith, 1999; Shmueli et al., 2006). The positioning of new information for deconstruction (de-framing) and re-construction (re-framing) is an important point to keep in mind, particularly when compiling an advocacy strategy. Reframing greatly benefits from constructive, trusting dialogue and establishing a context that enables and encourages new perspectives to be considered (Wals and Heymann, 2004; Shmueli et al., 2006).

\subsubsection{Advocacy}

The ecosystem services concept was developed primarily as an advocacy tool (Lele et al., 2013) (Fig. 3). Common to most definitions of advocacy, is the concept of changing in attitudes, positions or ideas. Information, education and communication are components of advocacy that persuade and mobilise people into action. Despite the importance of framing that "colours" people's perceptions and defines their choices, there is little reference to framing in the advocacy literature (Environmental Law Institute, 2004; Water Aid, 2007; UNICEF, 2010). However, there is general acknowledgement that values are important entities that will inform advocacy tactics, especially in terms of positioning messages (Water Aid, 2007; UNICEF, 2010). Providing new information that challenges or questions values may enable people to re-frame their perspective and position. Reframing is inherently difficult and requires spaces of constructive and trusting dialogue where risk and embarrassment of re-framing is minimised and/or new information would have to be presented so as to create incentives for new perspectives to be considered (Wals and Heymann, 2004; Shmueli et al., 2006).

\subsection{Unlocking investments}

Alteration, fragmentation and loss of habitat all contribute to biodiversity loss, a foundation of natural capital. Maintaining ecological networks is a solution, and has been subject to research, policy and practice for decades (Jongman et al., 2011; Čivić and Jones-Walters, 2014). South Africa's policy about ecological infrastructure (SANBI, 2014) and EU's Green infrastructure policy (European Commission, 2013) retain this ambition. They both aim at maintaining networks of strategically planned representative land-cover patches, which are designed and managed to conserve biodiversity and to deliver ecosystem services. This is very costly and insufficient state funding (e.g. Angelstam et al., 2011a) needs to be complemented by new frontiers of direct or indirect investments (Sullivan, 2013). Private landowner involvement is a key conservation challenge (Urgenson et al., 2013).

For investments in ecological infrastructure to be commercially attractive for the private sector there is usually a requirement for public sector funding to 'de-risk' (Fig. 3). De-risking is necessary because investing in ecological infrastructure tends to be pioneering with many uncertainties with regards to markets (e.g. REDD+ and carbon credits). In short, the markets for investing in ecological infrastructure are not mature, and the commercial activities are not tried and tested. There is a need to identify and define the market more succinctly, and deliver return on investments. This requires concerted effort of all actors and stakeholders to focus on innovation to overcome the barriers to commercialisation. Such innovation will rely on rapid changes in direction for private sector and government actors; and rigorous data collection to provide a platform for evidence-based collaboration and collaborative learning. Private sector investments involving the building of ecological infrastructure will invariably require capacity building in terms of business management. Where civil society does participate they are generally catalytic. The NGO sector is thus critical to unlocking investment in ecological infrastructure. Once a robust business case has been developed for private sector investment in ecological infra- 
structure, and financial mechanisms have been put in place to de-risk the investment, considerable marketing is required. Such marketing, with appropriately worded advocacy and marketing materials, would invariably require lengthy 'road shows' using snowballing to meet appropriate investors and to build relationships that ultimately culminate in large commercial deals. Without such relationship building, large investments from the private sector are unlikely to transpire.

Another requirement for investments in ecological infrastructure is a strong focus by all stakeholders on innovating, monitoring, and adaptively managing the ecological restoration process (Fig. 3). This will invariably require changing restoration protocols as rigorous data is collected and flaws are revealed in the original approaches (Mills et al., 2015). Given the inevitable complexity of ecosystem functioning, the development of restoration protocols should be viewed as a dynamic continual process with adaptive management, as opposed to a once-off event.

Finally, identification of champions in natural resource governance and management and analyses of how they manoeuvre in the social system is crucial (e.g. Dawson et al., 2017) (Fig. 3). There are many good (small-scale) examples of "green investments" (honeybush tea, wine, beer companies' supply chain and water conservation, agroforestry, ecotourism). For example, there has been a substantial increase in private sector investment in ecotourism, especially private game parks which links strongly to the conservation of biodiversity and ecosystem services (Sims-Castley et al., 2005). However, there is still a lack of buy in from other sectors, and the public. Borel-Saladin and Turok (2013) noted that green economic activity appears to generate more local jobs than fossil-fuel-based industries, and that this represents a promising starting point that warrants further research and policy involvement in greening the economy in South Africa. However, appropriate large-scale responses that influence ecosystem services emanating from landscapes are largely lacking (Mills et al., 2015). While this requires increased funding by several orders of magnitude, it needs to be put into the context of the long history of struggles over access to land and land rights in Africa (Bush and Szeftel, 2000; Meredith, 2005). Rapid flow of significant financial investments involves both opportunities and challenges in terms of understanding of international investors' ultimate objectives, and the spatial and temporal spread of benefits i.e. who benefits, where and when?

Currently, pressures on land resources have led to widespread leasing to foreign companies and governments for food production, development of tourism, biofuel production, and agricultural uses in Southern Africa (Bush et al., 2011). While the term 'land grabbing' is effective as activist terminology it hides the complex legality in land purchase and land tenure, and draws attention away from the roles of domestic governments, elites, intermediaries and beneficiaries. Büscher and Dressler (2012) found that the mediating role of foreign donors, NGOs and the private sector, were crucial for unleashing commodified conservation strategies. However, market-based interests often ignored resulting inequalities in local economies. An improved analytical framework to distinguish among various types of land deals will help to clarify the implications for land purchases and development in South Africa (Hall, 2011).

\section{Discussion}

\subsection{Landscape approach as transdisciplinary research}

Landscape restoration towards functional ecological infrastructure requires knowledge of the necessary conservation and management objectives that secure delivery of desired benefits in an equitable way at both the local scale and across entire landscapes. Satisfying these objectives requires action of and input from actors and stakeholders at multiple levels of decision-making. A key success factor is collaboration among owners and managers of land, water and other natural resources to improve stewardship, and integrated spatial planning.
Evidence-based knowledge from reference conditions representing the chosen level of ambition for landscape restoration and monitoring of progress are two crucial aspects to secure that expected outcomes are realised.

The gap between abundant research on ecological infrastructure and ecosystem services, as well as development activities on the one hand and limited implementation of collaborative learning and landscape stewardship including both governance and management on the other is hard to bridge (Sitas et al., 2014). Both insufficient knowledge and collaboration are barriers to be overcome. In the case study exploring the management of Prosopis in the Northern Cape, a lack of understanding and monitoring of ecological factors was a key barrier preventing early detection and response and hence more effective management. Thus, the focus on measuring social benefits and outcomes rather than ecological ones allowed the Prosopis invasions to increase until they reached an unmanageable state. This barrier highlights the need to improve ecological monitoring and early detection and rapid response (Wilson et al., 2013; Shackleton et al., 2016b, 2017b). National level plant invasions, regional invasive Prosopis and local natural resources management projects all suffer more or less from poor stakeholder engagement, which cause distrust among parties. Emerging collaborative learning in MAREP meetings help to address these aspects at the national scale, while at the local scale entities such as Living Lands, Flower Valley Trust, Conservation South Africa, Wildlands Conservation Trust, Endangered Wildlife Trust, WWF South Africa and others are playing a facilitating and collaborative learning role, which could help to overcome this barrier in the future.

If the history of use and modification of ecosystems is both long and intense, such as in many parts of South Africa, the delivery of ecosystem services is impaired. To improve human wellbeing, protection and sustainable management of ecosystems is necessary, but often insufficient. Additionally, landscape restoration involving innovations, engineering and practical skills are needed to secure the sustainable supply of ecosystem services for local and regional development (Stanturf et al., 2015; Sabogal et al., 2015). This requires a placebased process that sustains functional social-ecological systems by (1) production of evidence-based knowledge, and (2) cross-sectoral collaborative planning and management at multiple levels of societal steering. This is consistent with the landscape approach in natural resource governance and management (Axelsson et al., 2011; Sayers et al., 2014; Mbow et al., 2015) and transdisciplinarity in research (Hirsch Hadorn et al., 2008; Angelstam et al., 2013a).

The unifying term 'landscape' captures the manifold dimensions of places where people live and work (Vaccaro and Norman, 2008; Angelstam et al., 2013c). Climate, terrain, soils and the flow of water determine the particular types of natural ecosystems, and form the biophysical checkerboard that underpins the potential to deliver ecosystem services. These range from tangible goods and ecological functions to habitat for species, and cultural values. Anthropogenic modification of once natural ecosystems result in multifunctional cultural landscapes, agricultural fields, managed forests and built infrastructure. Finally, different landscapes provide perceived values, thereby shaping people's sense of place. The use of entire landscapes as spaces and places, thus including their social and ecological systems, in the form of case studies is an appropriate way of studying the complexity of actors' and stakeholders' ability to maintain ecological infrastructure by governance, management and monitoring of outcomes (e.g., Angelstam et al., 2013b). To restore landscapes require actions in both ecological and social systems.

Restoration after extraction of minerals and water regulation require physical actions, such as re-vegetation, removal of poisonous deposits, removal of dams to improve ecological connectivity and recreation of wetlands. Laissez-faire management, retention of forest edges, large trees and dead wood after forest harvest are examples of efforts to improve naturalness. While anthropogenic factors lead to 
alteration, fragmentation and loss of habitats, they may also improve human well-being and species' ability to persist (Lele et al., 2013).

Perceived landscape dimensions such as social capital can also be restored (Westlund and Kobayashi, 2013). Collaboration for landscape restoration builds relationships among people, improves social cohesion and therefore strengthens social capital. It can also increase many aspects of human wellbeing, and can enhance economic development. Creating "Green jobs" and contributing to the Green economy through landscape restoration can enable people to be custodians of nature that helps to ensure the delivery of vital ecosystem services, while also facilitating more inclusive socio-economic developments. Establishing the collaboration and "Working for..." initiatives amongst various actors requires special social and communicative skills. This is foundational for inclusive and sustainable landscape stewardship approaches, which also need to be adapted to the local governance context (Angelstam and Elbakidze, 2017). South Africa does indeed represent a complex governance context with a large proportion of land privately owned (Fig. 4). Some $67 \%$ is owned by historical white commercial farmers, $15 \%$ is communal land which is a sub set of state land, $10 \%$ is ordinary state land including conservation land (7\%), and 8\% is urban land (Walker and Dubb, 2017).

\subsection{International collaboration for functional ecological infrastructures}

Both regions and countries differ regarding how much their ecological systems have been modified, as well as the approaches to governance in the social system. Successful examples of landscape restoration and landscape approach as a means of transdisciplinarity can be scaled up and promoted through inspiring and well documented examples that cover the biophysical, anthropogenic and perceived dimensions of social-ecological systems (Carter and Currie-Alder, 2006; Dawson et al., 2017). These are excellent motives for international collaboration. Systematic comparative studies of landscapes in Europe's West and East demonstrate the feasibility of this approach (Angelstam et al., 2011b, 2013c). The BRICS countries (Brazil, Russia, India, China and South Africa) are emerging economies, with both considerable natural resources and abundant challenges, which could greatly benefit from this kind of knowledge sharing. In addition, experiences from landscapes and regions with different histories and governance systems in the global North and the South can provide improved knowledge and understanding to translate policy on ecological infrastructure to functional networks of representative land covers.

The use of multiple place-based studies improves the understanding of the dynamics presented and the need to engage diverse research disciplines and stakeholders in social-ecological systems, especially when the linkages between phenomenon and context are not visible (Flyvbjerg, 2006, 2011). By using multiple place-based case studies in a 'compass and gyroscope' approach (Lee, 1994), evidence-based knowledge can provide descriptions of different settings, develop theories, test hypotheses, and facilitate multi-level collaborative learning by empowering and engaging stakeholders (Stake, 1995; Clark, 2002; Flyvbjerg, 2006).

The proliferation of landscape restoration efforts and landscape approach concepts and applications on the ground provides excellent opportunities for multi-level learning based on comprehensive analyses of local initiatives within different national and international networks (Axelsson et al., 2011, 2013a). The sharing of quality-assured practices across national and international networks (e.g., NRM concepts like "Working for..." in South Africa, Biosphere Reserves, Model Forest, Long-Term Socio-Ecological Research platforms, Ecomuseum etc.) can facilitate learning through evaluation to ultimately improve governance, planning and management towards functional ecological infrastructure (Reed and Egunyu, 2013; Angelstam and Elbakidze, 2017). However, this will require comprehensive funding not only for landscape restoration, but also to establish transdisciplinary research infrastructures and enable collaborative learning opportunities (e.g., Mirtl et al., 2013).

\section{Conclusions}

Policies and investments into ecological infrastructure have so far delivered scattered research and development outcomes in both ecological and social systems at the local level. However, delivery of functional ecosystems and genuine progress at the levels of regions and nations require more. Key to managing and investing in ecological infrastructure, and the potential for delivering ecosystem services, is to understand their status and value to people, and to monitor changes. The need for social assessments and cohesion are paramount, as well as

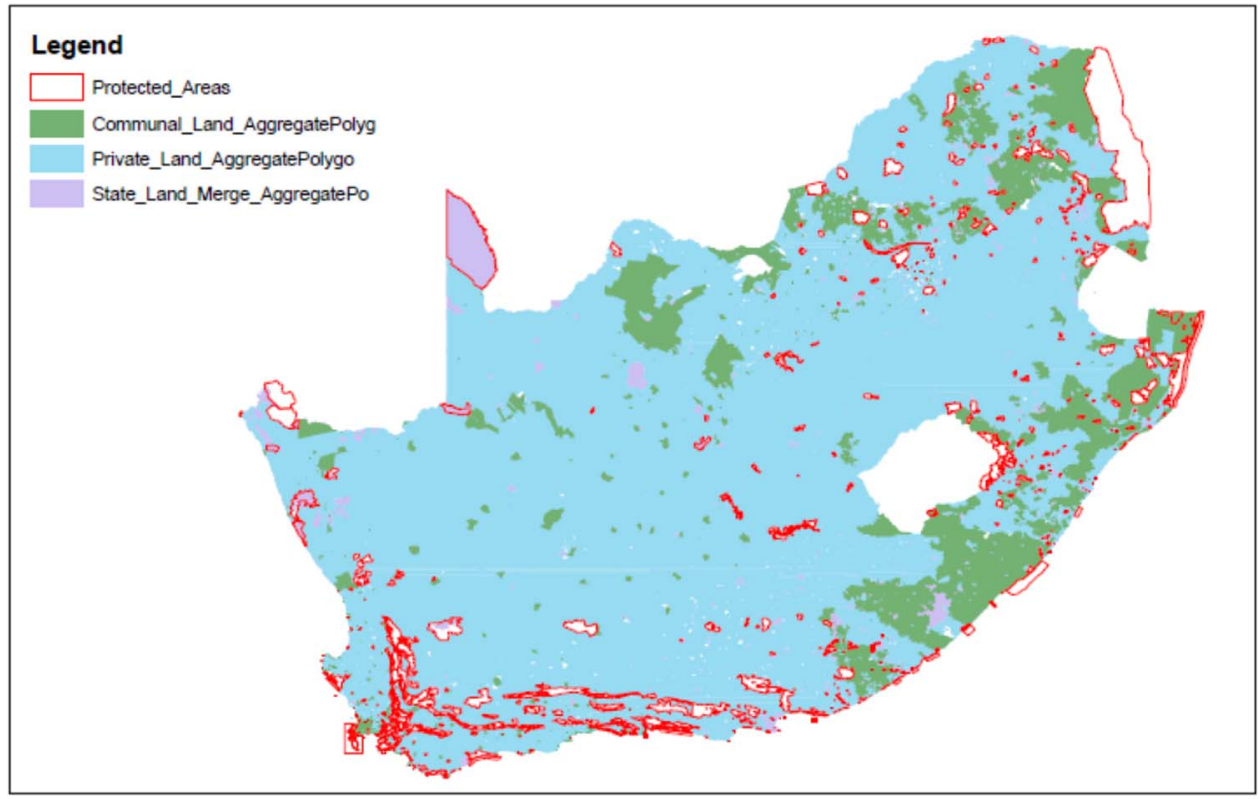

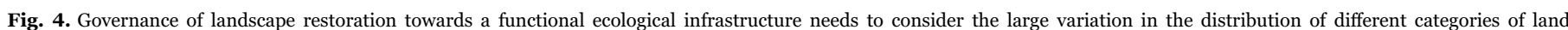
ownership in South Africa (see Walker and Dubb, 2017). 
the monitoring supply and demand of ecosystem services. Although not often acknowledged, much of the challenges faced by the ecological restoration sector are about financial resources. We highlight the need for integration of three key topics: local place-based collaborative learning; scaling up solutions to governance, management and monitoring of outcomes, based on good examples from multiple places; and the un-locking of funding for strategic, tactical and operational investments to improve human well-being overall. Because these challenges are universal, we argue for international collaboration for conservation, management and restoration of functional ecological infrastructures. Streamlining and applying the portfolio of actions to collaborative learning and unlocking of investment proposed in this paper can improve the maintenance of representative and functional ecological infrastructure at different spatial scales both in South Africa and globally.

\section{Acknowledgements}

The lead author's (PA) work on this paper was funded through the Swedish Research Council FORMAS as part of the project "Green infrastructures for ecological sustainability and human well-being: a network of forest, rural and urban landscapes as laboratories for integrative research" (grant number 2011-1737). DMR acknowledges support from the DST-NRF Centre of Excellence for Invasion Biology and the National Research Foundation (grant 85417). We thank Anthony Mills and three reviewers for valuable comments.

\section{References}

Angelstam, P., Andersson, L., 2001. Estimates of the needs for forest reserves in Sweden. Scand. J. For. Res. Suppl. 3, 38-51.

Angelstam, P., Elbakidze, M., 2017. Forest landscape stewardship for functional green infrastructures inEurope's West and East: diagnosing and treating social-ecological systems. In: Bieling, C., Plieninger, T. (Eds.), The Science and Practice of Landscape Stewardship.. Cambridge University Press, 124-144.

Angelstam, P., Dönz-Breuss, M. and Roberge, J.-M. (Eds.) Targets and tools for the maintenance of forest biodiversity. Ecological Bulletins 51, 2004, 1-510.

Angelstam, P., Elbakidze, M., Axelsson, R., Dixelius, M., Törnblom, J., 2013b. Knowledge production and learning for sustainable landscapes: seven steps using socialecological systems as laboratories. AMBIO 42, 116-128.

Angelstam, P., Andersson, K., Axelsson, R., Elbakidze, M., Jonsson, B.-G., Roberge, J.M., 2011a. Protecting forest areas for biodiversity in Sweden 1991-2010: policy implementation process and outcomes on the ground. Silva Fenn. 45, 1111-1133.

Angelstam, P., Mikusinski, G., Rönnbäck, B.I., Östman, A., Lazdinis, M., Roberge, J.M., Arnberg, W., Olsson, J., 2003. Two-dimensional gap analysis: a tool for efficient conservation planning and biodiversity policy implementation. AMBIO 32, 527-534.

Angelstam, P., Axelsson, R., Elbakidze, M., Laestadius, L., Lazdinis, M., Nordberg, M., Pătru-Stupariu, I., Smith, M., 2011b. Knowledge production and learning for sustainable forest management: european regions as a time machine. Forestry 84 $581-596$.

Angelstam, P., Grodzynskyi, M., Andersson, K., Axelsson, R., Elbakidze, M., Khoroshev, A., Kruhlov, I., Naumov, V., 2013c. Measurement, collaborative learning and research for sustainable use of ecosystem services: landscape concepts and Europe as laboratory. AMBIO 42, 129-145.

Angelstam, P., Andersson, K., Annerstedt, M., Axelsson, R., Elbakidze, M., Garrido, P., Grahn, P., Jönsson, K.I., Pedersen, S., Schlyter, P., Skärbäck, E., Smith, M., Stjernquist, I., 2013a. Solving problems in social-ecological systems: definition, practice and barriers of transdisciplinary research. AMBIO 42, 254-265.

Arnstein, S., 1969. A ladder of citizen participation. J. Am. Inst. Plan 35, 216-224.

Axelsson, R., Angelstam, P., Elbakidze, M., Stryamets, N., Johansson, K.-E., 2011. Sustainable development and sustainability: landscape approach as a practical interpretation of principles and implementation concepts. J. Landsc. Ecol. 4, 5-30.

Axelsson, R., Angelstam, P., Degerman, E., Teitelbaum, S., Andersson, K., Elbakidze, M., Drotz, M.K., 2013b. Social and cultural sustainability: criteria, indicators and verifier variables for measurement and maps for vizualisation to support planning. AMBIO $42,215-228$.

Axelsson, R., Angelstam, P., Myhrman, L., Sädbom, S., Ivarsson, M., Elbakidze, M. Andersson, K., Cupa, P., Diry, C., Doyon, F., Drotz, M.K., Hjorth, A., Hermansson, J.O., Kullberg, T., Lickers, F.H., McTaggart, J., Olsson, A., Pautov, Yu, Svensson, L., Törnblom, J., 2013a. Evaluation of multi-level social learning for sustainable landscapes: perspective of a development initiative in Bergslagen, Sweden. AMBIO 42, $241-253$.

Balmford, A., 2003. Conservation planning in the real world: south Africa shows the way. Trends Ecol. Evol. 18, 435-438.

Bennett, B., Kruger, F.J., 2015. Forestry and water conservation in South Africa: history, science and policy. ANU Press, Canberra.

Blignaut, J., Aronson, J., de Groot, R., 2014. Restoration of natural capital: a key strategy on the path to sustainability. Ecol. Engin. 65, 54-61.

Blignaut, J., Elser, K.J., de Wit, M.P., Le Maitre, D., Milton, S.J., Aronson, J., 2013. Establishing the links between economic development and the restoration of natural capital. Curr. Opin. Environm. Sust. 5, 94-101.

Bond, P., 2000. Economic growth, ecological modernization or environmental justice? Conflicting discourses in post-apartheid South Africa. Capital. Nat. Social. 11, 33-61.

Borel-Saladin, J.M., Turok, I.N., 2013. The impact of the green economy on jobs in South Africa. S. Afr. J. Sci. 109, 1-4.

Brumelis, G., Jonsson, B.G., Kouki, J., Kuuluvainen, T., Shorohova, E., 2011. Forest naturalness in northern Europe: perspectives on processes, structures and species diversity. Silva Fen. 45, 807-821.

Burkhard, B., Kroll, F., Nedkov, S., Müller, F., 2012. Mapping ecosystem service supply, demand and budgets. Ecol. Indic. 21, 17-29.

Büscher, B., Dressler, W., 2012. Commodity conservation: the restructuring of community conservation in South Africa and the Philippines. Geoforum 43, 367-376.

Bush, R., Szeftel, M., 2000. Commentary: the struggle for land. Rev. Afr. Polit. Econ. 27, $173-180$.

Bush, R., Bujra, J., Littlejohn, G., 2011. The accumulation of dispossession. Rev. Afr. Polit. Econ. 38 (128), 187-192.

Carter, S.E., Currie-Alder, B., 2006. Scaling-up natural resource management: insights from research in Latin America. Devel. Prac. 16, 128-140.

Čivić, K., Jones-Walters, L.M., 2014. Implementing green infrastructure and ecological networks in Europe: lessons learned and future perspectives. J. Green. Eng. 4, 307-324.

Clark, T.W., 2002. The policy processA practical guide for natural resource professionals. Yale University Press, New Haven and London.

Costanza, R., d’Arge, R., de Groot, R., Farber, S., Grasso, M., Hannon, B., Limburg, K., Naeem, S., O’Nell, R.V., Paruelo, J., Raskin, R.G., Sutton, P., van den Belt, M., 1997. The value of the world's ecosystem services and natural capital. Nature 387, 253-260.

Cowling, R.M., Pressey, R.L., Roget, M., Lombard, A.T., 2003. A conservation plan for a global biodiversity hotspot - the Cape Floristic region, South Africa. Biol. Conserv. $112,191-216$.

Cowling, R.M., Egoh, B., Knight, A.T., O’Farrel, P., Reyers, B., Rouget, M., Roux, D.J., Welz, A., Wilhelm-Rechman, A., 2008. An operational model for mainstreaming ecosystem services for implementation. Proc. Nat. Acad. Sci. USA 105, 9483-9488.

Daily, G. (Ed.), 1997. Nature's services: societal dependence on natural ecosystems. Island Press.

Daniels, S.E., Walker, G.B., 2001. Working through Environmental Conflict- The Collaborative Learning Approach. Praeger, Westport.

Dawson, L., Elbakidze, M., Angelstam, P., Gordon, J., 2017. Governance and management dynamics of landscape restoration at multiple scales: learning from successful environmental managers in Sweden. J. Environ. Manag. 197, $24-40$.

DEA (Department of Environmental Affairs), 2013. Department Environmental Affairs Strategic overview. Available at: 〈https://www.environment.gov.za/sites/default/ files/docs/201318strategic_overview.pdf).

Dzikiti, S., Schachtschneider, K., Naiken, V., Gush, M., Moses, G., Le Maitre, D.C., 2013 Water relations and the effects of clearing invasive Prosopis trees on groundwater in an arid environment in the Northern Cape, South Africa. J. Arid Environ. 90, $103-113$.

Elbakidze, M., Angelstam, P., Sandström, C., Axelsson, R., 2010. Multi-stakeholder collaboration in Russian and Swedish Model Forest initiatives: adaptive governance towards sustainable forest management? Ecol. Soc. 15, 14.

Elbakidze, M., Hahn, T., Mauerhofer, V., Angelstam, P., Axelsson, R., 2013. Legal framework for biosphere reserves as learning sites for sustainable development: a comparative analysis of Ukraine and Sweden. AMBIO 42 (2), 174-187.

Environmental Law Institute, 2004. A Toolkit for Environmental Advocacy in Africa, final draft.

European Commission, 2013. Green Infrastructure (GI) - Enhancing Europe's Natural Capital. COM 249.

Fahrig, L., 2001. How much habitat is enough? Biol. Conserv. 100, 65-74.

Fahrig, L., 2003. Effects of habitat fragmentation on biodiversity. Ann. Rev. Ecol. Evol. Syst. $34,487-515$.

Fahrig, L., 2002. Effect of habitat fragmentation on the extinction threshold: a synthesis. Ecol. Appl. 12, 346-353.

Farley, J., Erickson, J.D., Daly, H.E., 2005. Ecological economics. A workbook for problem-based learning. Island Press, Washington.

Flyvbjerg, B., 2006. Five misunderstandings about case-study research. Qual. Inq. 12, $219-245$.

Flyvbjerg, B., 2011. Case study. In: Denzing, N.K., Lincoln, Y.S. (Eds.), The Sage handbook of qualitative research.. Sage, Thousand Oaks, 310-316.

Fowkes, S., 2007. Lessons from changes in governance of fire management: the Ukuvuka Operation Firestop CampaignGovernance as a Trialogue: Government-SocietyScience in Transition. Springer Berlin Heidelberg, 215-236.

Fraser, E.D.G., Dougill, A.J., Mabee, W.E., Reed, M., McAlpine, P., 2006. Bottom up and top down: analysis of participatory processes for sustainability indicator identification as a pathway to community empowerment and sustainable environmental management. J. Environ. Manag. 78, 114-127.

Gasparatos, A., Takeuchi, K., Elmqvist, T., Fukushi, K., Nagao, M., Swanepoel, F., Swilling, M., Trotter, D., von Blottnitz, H., 2016. Sustain. Sci. Meet. Afr.'S. Chall. Sust. Sci. 11, 371-372.

Giordano, T., Blignaut, J., Marais, C., 2012. Natural resource management - an employment catalyst: the case of South Africa. Dev. Bank South. Afr. (DBSA). Dev. Plan. Div. Work. Pap. Ser. No., 33.

Goffman, E., 1974. Frame analysis: an essay on the organization of experience. Harvard 
University Press, Cambridge, MA.

Gray, B., 2004. Strong opposition: frame-based resistance to collaboration. J. Comm. Appl. Soc. Psychol. 14, 166-176.

de Groot, R., Brander, S., van der Ploeg, S., Constanza, R., Bernard, F., Braat, L., Christie, N., Crossman, N., Ghermandi, A., Hein, L., Hussain, S., Kumar, P., McVittie, A., Portela, R., Rodriguez, L.C., ten Brink, P., van Beukering, P., 2012. Global estimates of the value of ecosystems and their services in monetary unites. Ecosyst. Serv. 1, $50-61$.

de Groot, R.S., Alkemade, R., Braat, L., Hein, L., Willemen, L., 2010. Challenges in integrating the concept of ecosystem services and values in landscape planning, management and decision making. Ecol. Complex. 7, 260-272.

Groves, C.R., Jensen, D.B., Valutis, L.L., Redford, K.H., Shaffer, M.L., Scott, J.M., Baumgartner, J.V., Higgins, J.V., Beck, M.W., Anderson, M.G., 2002. Planning for Biodiversity Conservation: putting Conservation Science into Practice. BioScience $52,499-512$.

Hall, R., 2011. Land grabbing in Southern Africa: the many faces of the investor rush. Rev. Afr. Polit. Econ. 38, 193-214.

Hardin, R., 2002. Trust and Trustworthiness. Russell Sage Foundation.

Hirsch Hadorn, G., Hoffmann-Riem, H., Biber-Klemm, S., Grossenbacher-Mansuy, W. Joye, D., Pohl, C., Wiesmann, U., Zemp, E., 2008. Handbook of transdisciplinary research. Springer, Dordrecht.

Hoffman, M.T., Todd, S., 2000. National review of land degradation in South Africa: the influence of biophysical and socio-economics factors. J. Sth. Afr. Stud. 26, 743-759.

Jongman, R.H.G., Bouwma, I.M., Griffioen, A., Jones-Walters, L., Van Doorn, A.M., 2011. The Pan European Ecological Network: PEEN. Landsc. Ecol. 26, 311-326.

Kabanoff, B., 1991. Equity, equality, power and conflict. Acad. Manag. Rev. 16, 416-441.

Kates, R.W., 2011. What kind of science is sustainability science? Proc. Nat. Acad. Sci. USA 10, 19449-19450.

Kaufman, S., Smith, J., 1999. Framing and reframing in the land use conflicts. J. Arch. Plan. Res. 16, 164-180.

Keen, M., Mahanty, S., 2006. Learning in sustainable natural resource management: challenges and opportunities in the Pacific. Soc. Nat. Resour. 19, 497-513.

Kosoy, N., Corbera, E., 2010. Payments for ecosystem services as commodity fetishism. Ecol. Econ. 69, 1228-1236.

Kotzé, I., Beukes, H., Van den Berg, E., Newby, T., 2010. National invasive alien plant survey. agricultural research Council, Institute for soil. Clim. andWater, (Report No. GW/A/2010/21).

Lee, K.N., 1994. Compass and Gyroscope: Integrating Science and Politics for the Environment. Island Press.

Lele, S., Springate-Baginski, O., Lakerveld, R., Deb, D., Dash, P., 2013. Ecosystem services: origins, contributions, pitfalls, and alternatives. Conserv. Soc. 11, 343-358.

Lõhmus, A., Kohv, K., Palo, A., Viilma, K., 2004. Loss of old-growth, and the minimum need for strictly protected forests in Estonia. Ecol. Bull. 51, 401-411.

Lotz-Sisitka, H., 2012. (Re)Views on Social Learning Literature: A monograph for social learning researchers in natural resource management and environmental education. Grahamstown/Howick: Environmental Learning Research Centre, Rhodes University/EEASA/SADC REEP.

Lundquist, L., 1987. Implementation Steering An Actor-Structure Approach. Studentlitteratur, Lund.

Margules, C.R., Pressey, R.L., 2000. Systematic conservation planning. Nature 405, 243-253

Marsh, G.P., 1864. Man and Nature; or, Physical Geography as Modified by Human action. Charles Scribner, New York.

Mbow, C., Neely, C., Dobie, P., 2015. How can an integrated landscape approach contribute to the implementation of the Sustainable Development Goals (SDGs) and advance climate-smart objectives? In: Minang, P.A., van Noordwijk, M., Freeman, O.E., Mbow, C., de Leeuw, J., Catacutan, D. (Eds.), Climate-Smart Landscapes: Multifunctionality in Practice. World Agroforestry Centre, Nairobi, Kenya, 103-117, (ICRAF)

MEA (Millennium Ecosystem Assessment), 2005. Ecosystems and Human Well-being: Synthesis. Island Press, Washington DC.

Meredith, M., 2005. The State of Africa. Simon \& Schuster, London.

Merlo, M., Croitoru, L., 2005. Concepts and methodology: a first attempt towards quantification. In: Merlo, M., Croitoru, L. (Eds.), Valuing Mediterranean forests. Towards total economic value. CABI Publishing, Wallingford, 17-36.

Mikusiński, G., Edenius, L., 2006. Assessment of spatial functionality of old forest in Sweden as habitat for virtual species. Scand. J. For. Res. 21 (S7), 73-83.

Mills, A.J., Turpie, J., Cowling, R.M., Marais, C., Kerley, G.I.H., Lechmere, O.R.G., Sigwela, A.M., Powell, M., 2007. Assessing costs, benefits and feasibility of subtropical thicket restoration in the Eastern Cape, South Africa. In: Aronson, J., Milton, S.J. (Eds.), Restoring Natural Capital. Science, Business and Practice.. Island Press, Washington, DC, USA, 179-187.

Mills, A.J., van der Vyver, M., Gordon, I.J., Patwardhan, A., Marais, C., Blignaut, J., Sigwela, A., Kgope, B., 2015. Prescribing innovation within a large-scale restoration programme in degraded subtropical thicket in South Africa. Forests 6, 4328-4348.

Mirtl, M., Orenstein, D.E., Wildenberg, M., Peterseil, J., Frenzel, M., 2013. Development of LTSER platforms in LTER-Europe: challenges and experiences in implementing place-based long-term socio-ecological research in selected regionsLong Term SocioEcologicalResearch. Springer, Netherlands, 409-442.

Moser, S.C., Ekstrom, J.A., 2010. A framework to diagnose barriers to climate change adaptation. Proc. Nat. Acad. Sci. USA 107, 22026-22031.

Norgaard, R.B., 2010. Ecosystem services: from eye-opening metaphor to complexity blinder. Ecol. Econ. 69, 1219-1227.

Noss, R.F., 1990. Indicators for monitoring biodiversity: a hierarchical approach. Conserv. Biol. 4, 355-364.

NRM programmes, 2017. Natural Resource Management Programmes. (accessed 5 April
2017). 〈https://sites.google.com/site/nrmprogrammes/〉.

Odum, E.P., 1959. Fundamentals of Ecology 2nd ed. W.B. Saunders, Philadelphia.

Olson, D.M., Dinerstein, E., 2002. The Global 200: priority ecoregions for global conservation. Ann. Miss. Bot. Gard. 89, 199-224.

Pahl-Wostl, C., Craps, M., Dewulf, A., Mostert, E., Tabara, D., Taillieu, T., 2007. Social learning and water resources management. Ecol. Soc. 12, 5.

Peterken, G.F., 1996. Natural woodland: ecology and conservation in northern temperate regions. Cambridge University Press.

Pressey, R.L., Cowling, R.M., Rouget, M., 2003. Formulating conservation targets for biodiversity pattern and process in the Cape Floristic Region, South Africa. Biol. Conserv. 112, 99-127.

Rauschmayer, F., Berghöfer, A., Omann, I., Zikos, D., 2009. Examining processes or/and outcomes? Evaluation concepts in European governance of natural resources. Environ. Policy Gov. 19, 159-173.

Reed, M.G., Egunyu, F., 2013. Management effectiveness in UNESCO Biosphere Reserves: learning from Canadian periodic reviews. Environm. Sci. Pol. 25, $107-117$.

Sabogal, C., Besacier, C., McGuire, D., 2015. Forest and landscape restoration: concepts, approaches and challenges for implementation. Unasylva 66, 3-10.

San Martín-Rodríguez, L., Beaulieu, M.D., D'Amour, D., Ferrada-Videla, M., 2005. The determinants of successful collaboration: a review of theoretical and empirical studies. J. Inter. Care. 19 (Suppl. 1), 132-147.

SANBI, 2014. A Framework for investing in ecological infrastructure in South Africa. South African National Biodiversity Institute, Pretoria.

Saura, S., Torne, J., 2009. Conefor Sensinode 2.2: a software package for quantifying the importance of habitat patches for landscape connectivity. Environm. Mod. Softw. 24, $135-139$.

Saura, S., Estreguil, C., Mouton, C., Rodríguez-Freire, M., 2011. Network analysis to assess landscape connectivity trends: application to European forests (1990-2000). Ecol. Indic. 11, 407-416.

Sayer, J., Sunderland, T., Ghazoul, J., Pfund, J.L., Sheil, D., Meijaard, E., Venter, M., Boedhihartano, A., K., Day, M., Garcia, C., van Oosten, C., Buck, L.E., 2013. Ten principles for a landscape approach to reconciling agriculture, conservation, and other competing land uses. Proc. Nat. Acad. Sci. USA 110, 8349-8356.

Shackleton, C.M., Ruwanza, S., Sanni, G.S., Bennett, S., De Lacy, P., Modipa, R., Mtati, N., Sachikonye, M., Thondhlana, G., 2016a. Unpacking Pandora's box: understanding and categorising ecosystem disservices for environmental management and human wellbeing. Ecosystems 19, 587-600.

Shackleton, R.T., Le Maitre, D.C., Richardson, D.M., 2015. Stakeholder perceptions and practices regarding Prosopis (mesquite) invasions and management in South Africa. AMBIO 44, 529-536.

Shackleton, R.T., Le Maitre, D.C., van Wilgen, B.W., Richardson, D.M., 2016b. Identifying barriers to effective management of widespread invasive alien trees: prosopis species (mesquite) in South Africa as a case study. Glob. Environm. Change 38, 183-194.

Shackleton, R.T., Angelstam, P., van der Wall, B., Elbakidze, M., 2017a. Progress made in managing and valuing ecosystem services: a horizon scan of gaps in research, management and governance. Ecosyst. Serv.. http://dx.doi.org/10.1016/ j.ecoser.2016.11.020.

Shackleton, R.T., Le Maitre, D.C., van Wilgen, B.W., Richardson, D.M., 2017b. Towards a national strategy to optimise the management of a widespread invasive tree (Prosopis species; mesquite) in South Africa. Ecosyst. Serv.. http://dx.doi.org/ 10.1016/j.ecoser.2016.11.022.

Shea, K., Possingham, H.P., Murdoch, W.W., Roush, R., 2002. Active adaptive management in insect pest and weed control: intervention with a plan for learning. Ecol. Appl. 12 (3), 927-936.

Shmueli, D., Elliott, M., Kaufman, S., 2006. Frame changes and the management of intractable conflicts. Confl. Resolut. Q., Colloquy Intractable Confl. 24, 207-218.

Sigwela, A., Elbakidze, M., Powell, M., Angelstam, P., 2017. Defining potential core areas of ecological infrastructure to secure ecosystem services for rural livelihoods in South Africa. Ecosystem Services, this issue.

Sims-Castley, R., Kerley, G.I.H., Geach, B., Langholz, J., 2005. Socio-economic significance of ecotourism-based private game reserves in South Africa's Eastern Cape province. Parks 1, 6-18.

Sitas, N., Prozekky, H.E., Esler, K.J., Reyers, B., 2014. Opportunities and challenges for mainstreaming ecosystem services in development planning: perspectives from a landscape level. Landsc. Ecol. 29, 1315-1331.

Stake, R.E., 1995. The art of case study research. Sage, London.

Stanturf, J.A., Kant, P., Barnekow, J.-P., Lillesø, M., Mansourian, S., Kleine, M., Graudal, L., Madsen, P., 2015. Forest landscape restoration as a key component of climate change mitigation and adaptation. IUFRO World Ser. 34.

Sterman, J.D., 2000. Business dynamics, system thinking and modelling for a complex world. Irwin McGraw-Hill, New York.

Sullivan, S., 2013. Banking Nature? The spectacular financialisation of environmental Conservation. Antipode 45, 198-217.

Sutton, P.C., Costanza, R., 2002. Global estimates of market and non-market value derived from night time satellite imagery, land cover, and ecosystem service valuation. Ecol. Econ. 41, 509-527.

Svancara, L.K., Scott, M., Groves, C.R., Noss, R.F., Pressey, R.L., 2005. Policy-driven versus evidence-based conservation: a review of political targets and biological needs. BioScience 55, 989-995.

Tear, T.H., Kareiva, P., Angermeier, P.L., Comer, P., Czech, B., Kautz, R., Landon, L., Mehlman, D., Murphy, K., Ruckelshaus, M., Scott, J.M., Wilhere, G., 2005. How much is enough? The recurrent problem of setting measurable objectives in conservation. BioScience 55, 836-849.

Tischendorf, L., Fahrig, L., 2000. On the usage and measurement of landscape 
connectivity. Oikos 90, 7-19.

UNICEF, 2010. Advocacy Toolkit. A guide to influencing decisions that improve children's lives. United Nations Children's Fund (UNICEF), New York.

Urgenson, L.S., Prozesky, H.E., Esler, K.J., 2013. Stakeholder perceptions of an ecosystem services approach to clearing invasive alien plants on private land. Ecol. Soc. 18 (1), 26.

Vaccaro, I., Norman, K., 2008. Social sciences and landscape analysis: opportunities for the improvement of conservation policy design. J. Environm. Manag. 88, 360-371.

van Wilgen, B.W., Wannenburgh, A., 2016. Co-facilitating invasive species control, water conversation and poverty relief: achievements and challenges in South Africa's working for Water programme. Curr. Opin. Environm. Sustain 18, 7-17.

van Wilgen, B.W., Fill, J.M., Baard, J., Cheney, C., Forsyth, A.T., Kraaij, T., 2016b. Historical costs and projected future scenarios for the management of invasive alien plants in protected areas in the Cape Floristic Region. Biol. Conserv. 200, 168-177.

van Wilgen, B.W., Forsyth, G.G., Le Maitre, D.C., Wannenburgh, A., Kotze, D.F., van den Berg, E., Henderson, L., 2012. An assessment of the effectiveness of a large, nationalscale invasive alien plant control strategy in South Africa. Biol. Conserv. 148, 28-38.

van Wilgen, B.W., Carruthers, J., Cowling, R.M., Esler, K.J., Forsyth, A.T., Gaertner, M., Hoffman, M.T., Kruger, F.J., Midgley, G.F., Palmer, G., Pence, G., Raimondo, D.C., Richardson, D.M., van Wilgen, N.J., Wilson, J.R.U., 2016a. Ecological research and conservation management in the Cape Floristic Region between 1945 and 2015 history, current understanding and future challenges. Trans. R. Soc. S. Afr. 71, 207-303.

Vaz, A.S., Kull, C.A., Kueffer, C., Richardson, D.M., Vicente, J.R., Kühn, I., Schröter, M., Hauck, J., Bonn, A., Honrado, J.P., 2017. Integrating ecosystem disservices and services: insights from plant invasions. Ecosyst. Serv. 23, 94-107.

Villard, M.-A., Jonsson, B.G., 2009. Setting Conservation Targets for Managed Forest Landscapes. Cambridge University Press, Cambridge.

Vogt, P., Ferrari, J.R., Lookingbill, T.R., Gardner, R.H., Riitters, K.H., Ostapowicz, K., 2009. Mapping functional connectivity. Ecol. Indic. 9, 64-71.

von Carlowitz, H.C., 1713. (2000)In: Irmer, K. (Ed.), Sylvicultura oeconomica
[Economic forest management] oder Hausswirthliche Nachricht und naturmässige Anweisung zur wilden Baumzucht. Technische Universität Bergakademie Freiberg, Freiburg.

Walker, C., Dubb, A., 2017. The distribution of land in South Africa: an overview. Fact check No. 1 Land Reform. PLAAS. 〈http://www.plaas.org.za/sites/default/files/ publications-pdf/No1>.

Wals, A.E.J., 2007a. Learning in a changing world and changing in a learning world: Reflexively fumbling towards sustainability. S. Afr. J. Environm. Educ. 24, 35-45.

Wals, A.E.J., 2007b. Creating networks of conversations Social learning towards a sustainable world. : Wageningen Academic Publishers, The Netherlands.

Wals, A.E.J., Heymann, F.V., 2004. Learning on the edge: exploring the change potential of conflict in social learning for sustainable living. In: Wenden, A.L. (Ed.), Educating for a Culture of Social and Ecological Peace. State University of New York Press, New York.

Water Aid, 2007. The Advocacy Sourcebook WaterAid, Durham Street, London.

Westlund, H., Kobayashi, K., 2013. Social Capital And Rural Development in the Knowledge Society. Edward Elgar, Cheltenham.

Wilson, J.R.U., Ivey, P., Manyama, P., Nänni, I., 2013. A new national unit for invasive species detection, assessment and eradication planning. S Afr. J. Sci. 109 (5/6), 13 pages , (Art. \#0111)〈http://www.sajs.co.za/sites/default/files/publications/pdf/ wilson.pdf $\rangle$.

Wise, R.M.B., van Wilgen, B.W., Le Maitre, D.C., 2012. Costs, benefits and management options for an invasive alien tree species: the case of mesquite in the Northern Cape, South Africa. J. Arid Environ. 84, 30-90.

Woodford, D.J., Richardson, D.M., MacIsaac, H.J., Mandrak, N.E., van Wilgen, B.W., Wilson, J.R.U., Weyl, O.L.F., 2016. Confronting the wicked problem of managing biological invasions. Neobiota 31, 63-86.

Wynberg, R., 2002. A decade of biodiversity conservation and use in South Africa: tracking progress from the Rio earth summit to the Johannesburg world summit on sustainable development. S. Afr. J. Sci. 98, 233-243. 